\title{
O Princípio da Isonomia Tributária \\ e sua Aplicabilidade
}

\section{Juliana Evangelista Monteneqro Barbosa}

\section{INTRODUÇÃO}

A Constituição Federal de 1988 concedeu aos princípios papel de destaque em seu texto. O princípio da igualdade, não bastasse a sua normatização constante no artigo $5^{\circ}$, caput, da Constituição, encontra se preceituado por todo o texto constitucional, ganhando relevância, inclusive em matéria tributária, como pode ser verificado no artigo 150, inciso II, da Constituição, ao conceituar o princípio da igualdade na tributação, ou seja, o princípio da isonomia tributária.

Ocorre que, mesmo estando garantido pelo texto constitucional, o princípio da isonomia tributária é um instituto de difícil aplicação.

Assim, este trabalho tem o propósito de estudar o princípio da isonomia tributária e sua aplicabilidade, isto é, como aplicá-lo, compreendê-lo, interpretá-lo e utilizá-lo. Enfim, ter consciência da dimensão jurídica e da importância do princípio constitucional em estudo.

Para tanto, inicia-se este trabalho abordando o instituto da igualdade como princípio constitucional.

Nesta parte, faz-se necessário analisar alguns pontos de fundamental importância para o desenvolvimento do princípio da igualdade, tais como a distinção entre princípios e regras, a importância dessas normas no ordenamento jurídico, bem como o estudo sobre os princípios constitucionais.

Com o desenvolvimento dos pontos preliminares anteriormente referidos, segue-se o estudo com a abordagem do instituto da igualdade na Constituição Federal de 1988 . dando destaque ao caput do artigo $5^{\circ}$ do texto constitucional.

Evidencia-se, nesta etapa do estudo, a necessidade de desenvolver três pontos: a igualdade como um princípio fundamental, como um direito fundamental e sua aplicabilidade imediata. 

finalidades.

Além disso, importante destacar também as diferenciações de tratamento e suas

Com a finalização da primeira parte do trabalho, passa-se ao exame da isonomia como um princípio constitucional tributário, salientando Que a estrutura do direito tributário encontra-se na Constituição, ou seja, é no texto constitucional que estão preceituados os limites ao poder de tributar e onde se estruturam os princípios de natureza tributária, princípios esses que formam a base de sustentação de todo o sistema tributário.

Assim, com a análise do princípio da isonomia tributária, estabelecido no artigo 150 , inciso II, da Constituição, evidencia-se a necessária e imporłante abordagem de alguns pontos, tais como a vedação à arbitrariedade, os reQuisitos para a aplicação do princípio em estudo e os critérios para as diferenciaçōes de tratamento, critérios esses que auxiliam na verificação do tratamento dado aos contribuintes, ou sej̣a, na verificação se houve violação, ou não, ao princípio da isonomia tributária.

\section{O PRINCÍPIO CONSTITUCIONAL DA IGUALDADE}

Nesta seção, para a compreensão do princípio constitucional da igualdade, serão tratadas a distinção entre os princípios e regras, os aspectos relevantes sobre os princípios constitucionais e a igualdade na Constituição Federal de 1988.

\subsection{Princípios e Reqrias: Distinção e Importância}

Atualmente, vasta doutrina considera os princípios e as regras como sendo as duas espécies de norma jurídica. Assim, torna-se importante distinguí-las'.

Para Robert Alexy ${ }^{2}$, o ponto decisivo na distinção das normas é o fato de Que os princípios são normas Que ordenam a realização de algo na maior medida possível, dentro das possibilidades jurídicas e reais existentes, mas que carecem de conteúdo de determinaçăo, ao passo Que as regras são normas Que podem ser cumpridas ou nāo, ou seja, sempre contêm uma determinação, exigindo a feitura exata do seu ordenado.

Nesse sentido é também o entendimento de José Joaquim Gomes Canotilho ${ }^{3}$ Quando define as regras como sendo normas Que impōem, Que prescrevem algo a ser seguido em

1 A importância de distingulr as regras dos princípios é destacada por Robert Alexy, ao afirmar Que se trata da distinçăo mais importante para a teoria dos direitos fundamentais, haịa vista propiciar uma teorização sobre os limites e o papel dos direitos fundamentais no sistema jurídico (ALEXY, Robert. Teoria de Los Derechos Fundamentales. Madrid: Centro de Estudios Constitucionales, 1993. p. 81).

2 ALEXY, Robert. Teoria de Los Derechos Fundamentales. Madrid: Centro de Estudios Constitucionales, 1993. p. 99.

3 CANOTILHO, José Joaquim Gomes. Direito Consitucional e Teoria da Constituição. $5^{\text {a }}$ ed. Coimbra: Livraria Almedina, 2002. p. 1 [45, 1239. 
termos definitivos, ou seja, estabelecem uma exígência, a qual deve ser ou não cumprida, na medida exata dos seus ordenamentos. Em contrapartida, para o autor, os princípios são normas que exigem o cumprimento de algo da meihor forma possivel, possuindo graus distintos de materialização, permitindo assim o equilibrio de valores e interesses.

Destaca-se também análise feita por Humberto Ávila ${ }^{4}$, ao argumentar que os princípios possuem eficácia interpretativa por instituírem um estado ideal de coisas a ser alcançado e Que as regras são normas de maior rigidez, visto Que descrevem comportamento obrigatório. $\mathrm{O}$ autor ${ }^{5}$ complementa tal entendimento Quando menciona que as regras definem e delimitam comportamentos a serem adotados para a concretização do estabelecido pelos princípios.

Celso Ribeiro Bastos ${ }^{6}$ elucida Que a diferença entre princípios e regras não está só no grau de abstração dos princípios, mas também na aplicabilidade direta Que as regras possuem. Entretanto, mesmo havendo tais diferenças, esclarece que os princípios, juntamente com as regras, fazem parte do ordenamento jurídico, não se colocando além ou acima do direito, nem se contrapondo às regras, mas tão-somente aos preceitos.

Especificamente sobre o grau de abstração Que os princípios possuem, o autor ${ }^{7}$ esclarece oue os princípios, além de possuírem função ordenadora, outras vezes podem exercer ação direta, nesse caso Quando houver condições para serem auto-executáveis.

Outro posicionamento que convém referir é o de Walter Claudius Rothenburg ${ }^{8}$, para Quem as regras não conseguem expor integralmente os princípios, mas, Quanto à aplicação, a regra deve ser aplicada e interpretada em conformidade com os princípios.

Nessa mesma linha de pensamento, Sacha Calmon Navarro Coelho afirma Que os princípios não instituem comportamento específico, mas sim comportamento padrão, sem exigência de condições para sua aplicação, sendo utilizado apenas para a interpretação dos casos e das leis.

Do exposto, pode-se concluir que as regras e os princípios são dois tipos de normas jurídicas que exercem dentro do sistema normativo papéis distintos, mas que se complementam. As regras possuem a função de regular, direta ou indiretamente, as relações jurídicas Que se enquadram em situaçóes específicas por elas descritas. São normas de maior rigidez, haja vista descreverem comportamentos a serem seguidos.

4 ÁVILA, Humberto. Sistema Constitucional Tributário. São Paulo: Saraiva, 2004. p. 38-40.

ÁVILA, Humberto. Sistema Constitucional Tributário. São Paulo: Saraiva, 2004. p. 51 .

- BASTOS, Celso Ribeiro; MARTINS, Ives Gandra. Comentários à Constituição do Brasil. $1^{\circ}$ volume. São Paulo: Saraiva, 1988. p. 339.

7 BASTOS, Celso Ribeiro; MARTINS, Ives Gandra. Comentários à Constituição do Brasil. $1^{\circ}$ volume. São Paulo: Saraiva, 1988. p. 341-342.

8 ROTHENBURG, Walter Claudius. Princípios Constitucionais. Porto Alegre: Sergio Antonio Fabris Editor, 1999. p. 30-31.

9 COELHO, Sacha Calmon Navarro. Comentários à Constituição de 1988. Sistema Tributário. $6^{\mathrm{a}}$ ed. Forense: Rio de Janeiro, 1997. p. 106. 
lá os princípios possuem um teor maior de abstração, pois expressam um valor ou uma diretriz, e não uma exigência ou um comportamento, como no caso das regras. Assim, por serem de maior flexibilidade, os princípios são normas abertas à interpretação ${ }^{10}$.

Entretanto, cumpre frisar Que os princípios não possuem apenas a característica interpretativa. Os princípios, além de auxiliarem na interpretação das normas, são normas impositivas de valores.

Nesse sentido é o entendimento de Eros Roberto Grau" "ao diferenciar os princípios das regras. Segundo o autor, as duas espécies de norma possuem a generalidade como característica. Entretanto, especifica Que a regra é geral porQue é estabelecida para um número indeterminado de atos ou fatos, ao passo que o princípio é geral porque comporta uma série indefinida de aplicaçóes.

O autor também salienta Que os princípios, além de determinarem a interpretação das regras, atuam como mecanismo de controle de produção das regras, tornando-se, dessa forma, em medida de controle externo da produção das normas.

Importante ainda destacar entendimentos opostos com relação à hierareuia dessas duas espécies de normas jurídicas.

Conforme acima analisado, tanto os princípios como as regras possuem distintos e importantes papéis no ordenamento jurídico, papéis esses que se complementam, Que se aperfeiçoam, mas que em determinados casos podem se contrapor, se confrontar.

Para Ávila ${ }^{12}$, Quando princípio e regra, de mesmo nível hierárquico, estiverem em conllito, deve ser dada primazia à regra. Conforme o autor, o grau de conhecimento do dever a ser cumprido, no caso das regras, é muito maior Quando no caso dos princípios.

Assim, define que "descumprir o que já foi objeto de decisão é mais grave do que descumprir uma norma cuja função é servir de razão complementar ao lado de outras razões para futura decisão".

Em contrapartida, é outro o entendimento de Roque Antônio Carrazza ${ }^{13}$, ao argumentar Que os princípios cumprem importante papel dentro do ordenamento jurídico. haja vista sua função de direcionar, esclarecer e instruir, entre outras, a interpretação das normas jurídicas. Portanto, a aplicação das regras só se dará quando coerente com o estipulado pelos princípios.

10 Sobre a abertura, como característica dos princípios, ver: ÁVlıA, Humberto. Sistema Constitucional Tributărio. Săo Paulo: Saraiva, 2004. p. 59; CANOTILHO, losé loaquim Gomes. Direito Constitucional e Teoria da Constituiçăo. $5^{a}$ ed. Coimbra: Livraria Almedina, 2002. p. 1147.

"GRAU, Eros Roberto. Ensalo e Discurso sobre a Interpretação/Aplicação do Direito. $3^{a}$ ed. São Paulo: Malheiros Editores, 2005. p. 153, 183.

12 ÁVILA, Humberto. Sistema Constitucional Tributário. São Paulo: Saraiva, 2004. p. 53-54.

13 CARRAZZA, Roque Antônio. Curso de Direito Constitucional Tributário. $12^{\mathrm{a}}$ ed. São Paulo: Malheiros Editores, 1999 . p. 36, 38 . 
O autor segue seu posicionamento, Quando conceitua os princípios como normas indicativas e reguladoras da aplicabilidade de outras normas, por isso devendo ser sempre respeitados.

Nesse sentido, Celso Antônio Bandeira de Mello ${ }^{4}$ analisa que, pelo fato de a desatenção a um princípio implicar não apenas na ofensa de um mandamento específico, mas sim de todo o sistema de comandos, violar um princípio é mais grave que violar uma regra.

Ocorre Que, mesmo havendo entendimentos distintos sobre a prevalência das normas jurídicas, evidenciamse não só o caráter geral mas fundamental dos princípios.

É pertinente esclarecer que tal análise será novamente abordada no transcorrer do trabalho, haja vista sua importância para o desenvolvimento e para a compreensão do tema central, Qual seja, a aplicabilidade do princípio da isonomia tributária. Assim, seguindo o estudo dos aspectos preliminares, o ponto seguinte aborda os princípios dispostos na Constituição.

\subsection{Aspectos Relevantes sobre os Princípios Constitucionais}

A Constituição, no entendimento de Hans Kelsen ${ }^{15}$, é norma positiva que regula a produção de normas jurídicas gerais e determina o conteúdo das leis futuras. É onde encontram-se estabelecidos os princípios, em sua maioria.

Para Ingo Wolfgang Sarlet ${ }^{16}$ a Constituição é estatuto jurídico fundamental, é um sistema aberto de regras e princípios.

Na percepção de Canotilho ${ }^{17}$, a lei constitucional, considerada ordenação normativa fundamental, é dotada de supremacia.

Ainda sobre a Constituição, Carrazza ${ }^{18}$ destaca sua característica de lei máxima, de lei fundamental do Estado que representa o direito positivo mais elevado. Assim, é na Constituição Que se encontram as normas jurídicas de mais alto grau, devendo estas, portanto, estar em harmonia com as normas constitucionais.

Tal entendimento é complementado por Sarlet ${ }^{19}$ ao definir que toda norma constitucional é formada por determinado grau de eficácia normativa $e$ aplicabilidade.

${ }^{14}$ MELL.O, Celso Antônio Bandeira de. Elementos de Direito Administrativo. $1^{a}$ ed. São Paulo: Revista dos Tribunais, 1987. p. 230.

15 KELSEN, Hans. Teoria Pura do Direito. Tradução de João Baptista Machado. $6^{a}$ ed. São Paulo: Martins Fontes, 1998. p. 247-249.

${ }^{16}$ SARLET, ingo Wolfgang. A Eficácia dos Direitos Fundamentais. $2^{2}$ ed. Porto Alegre: Livraria do Advogado, 2001. p. 78.

${ }^{i 7}$ CANOTILHO, José Joaquim Gomes. Dircito Constitucional e Teoria da Constituiçâo. $5^{\text {a }}$ ed. Coimbra: Livraria Almedina, 2002. p. 245-246.

${ }^{18}$ CARRAZZA, Roque Antônio. Curso de Direito Constitucional Tributário. $12^{\mathrm{a}}$ ed. São Paulo: Mahtheiros Editores, 1999. p. 28/29.

19 SARLET, Ingo Wolfgang. A Eficácia dos Direitos Fundamentais. 2a ed. Porto Alegre: Livraria do Advogado, 200I. p. 234. 
Para elucidar tal abordagem, cumpre referir o estudo de Cármen Lúcia Antunes Rocha $^{20}$, Que conceitua princípio constitucional como sendo o elemento essencial ao ordenamento jurídico, visto ser a base formal e material da construção normativa, dando fundamento à regra jurídica.

Apoia-se também, neste ponto, em lição de Rothenburg' ${ }^{21}$, ao conceituar os princípios constitucionais como sendo normas dispostas por toda a Constituiçâo, Que estabelecem os valores essenciais de apoio e orientação à sociedade.

Desse modo, a violação dos princípios constitucionais, Que caracterizam-se de uma normatividade potencializada e predominante, estará revestida de ilegalidade ou inconstitucionalidade, representando não só oposição ao estipulado pelo princípio mas também ao estipulado por todo o sistema, e em especial pelo seus valores fundamentais ${ }^{22}$.

Logo, chega-se ao seguinte denominador: os princípios constitucionais são preceitos respaldados em valores fundamentais Que têm como função conduzir e orientar outras normas, não só no âmbito constitucional, mas em todo o ordenamento jurídico. Mesmo possuindo diferentes graus de concretização, os princípios constitucionais possuem aplicabilidade e eficácia normativa.

Por isso, apresentam-se os princípios constitucionais como normas de máxima importância e relevância, não só por regulamentarem valores orientadores de normas jurídicas, mas também por instituírem comportamento padrão $0^{23}$, por regulamentarem diretrizes a serem seguidas. Portanto, são normas Que expressam valores Que orientam a sociedade como um todo.

\subsection{A Iqualdade na Constituição Federal de 1988}

Para a abordagem desta subseção, será dado destaque ao artigo $5^{\circ}$ da Constituição Federal, evidenciando-se, com isso, a necessária e conveniente divisão desta subseção em outros três pontos: a igualdade como um princípio fundamental, como um direito fundamental e sua aplicabilidade imediata. Além disso, destaque foi dado às diferenciações de tratamento e suas finalidades.

ROCHA, Cármen Lúcia Antunes. O Princípio Constitucional da lgualdade. Belo Horizonte: Lê, 1990. p. 19.

ROTHENBURG, Walter Claudius. Aincipios Consttucionais. Porto Alegre: Sergio Antonio Fabris Editor, 1999. p. 81.

27 Nesse sentido: MELLO, Cẹtso Antônio Bandeira de. Elementos de Direito Administrativo. São Paulo: Revista dos Tribunais, 1983. p. 230. Sobre a hierarquia das normas juridicas, importante novamente frisar o entendimento de Humberto Ávila, examinado na subseçăo 1.1 deste trabalho.

${ }^{23}$ Nesse sentido, ver posicionamento de Sacha Calmon Navarro Coelho, transcrito na subseção 1.1 deste trabalho. 


\subsubsection{Igualdade como Princípio Fundamental}

A Constituição da República Federativa do Brasil, promulgada em 05 de outubro de 1988, institui, em seu Preâmbulo²4, um Estado Democrático destinado a assegurar, entre outros direitos, a igualdade.

Cármen Lúcia Antunes Rocha ${ }^{25}$ ressalta Que a Constituição de 1988 fora a primeira Que especificou no seu Preâmbulo a igualdade como princípio determinante na elaboração do sistema normativo fundamental.

Seguindo a análise do texto constitucional, vale destacar Que a parte inaugural da Constituição possui como título primeiro "Dos Princípios Fundamentais"26. Entretanto, conforme anteriormente referido ${ }^{27}$, os princípios constitucionais não limitam-se apenas à parte destinada a eles na Constituição, estando dispostos por todo o texto constitucional.

O constituinte assegurou tal posicionamento ao estabelecer no caput do artigo $5^{\circ} \mathrm{da}$ Constituição $0^{28}$, a garantia de Que todos são iguais perante a lei, ou seja, o princípio da igualdade. Desta maneira, ressalta-se o papel de destaque que o instituto da igualdade tem no texto constitucional; destaque esse bem salientado por Aliomar Baleeiro ${ }^{29}$ ao definir a igualdade como sendo o pilar básico do Estado Democrático de Direito.

Canotitho ${ }^{30}$ completa o entendimento acima Quando alega Que o princípio da igualdade não se caracteriza somente como um princípio de igualdade de Estado de Direito, mas também como um princípio de igualdade de democracia econômica e social.

Nesse contexto, Cármen Rocha ${ }^{31}$ institui Que as normas constitucionais de maior expressão são as contidas no art. $5^{\circ} \mathrm{da}$ Constituição, visto Que não sofrem impedimentos de outras normas do sistema constitucional. Continua a destacar o papel da igualdade na Constituição, ao referir que a igualdade jurídica, por estar contida no início do artigo $5^{\circ} \mathrm{da}$

${ }^{24}$ Cármen Lúcia Antunes Rocha, define o preâmbulo como sendo o enunciado preliminar, Que especifica valores Que nortearam os constituintes. Näo possui o preâmbulo aplicabilidade, mas traça o caminho a ser seguido pelas normas @ue compöem o sistema constitucional (ROCHA, Cármen Lúcia Antunes. O Princípio Constitucional da Igualdade. Belo Horizonte: Lê, 1990. p. 67).

${ }^{25}$ ROCHA, Cármen Lúcia Astunes. O Princípio Constitucional da lgualdade. Belo Horizonte: Lê, 1990. p. 67.

26 A Constituição de 1988 também foi a primeira Constituição Brasilèira à destinar uma parte especialmente aos princípios fundamentais (SARLET, Ingo Woligang. A Eficácia dos Direitos Fundamentais. $2^{\text {a }}$ ed. Porto Alegre: Livraria do Advogado, 2001. p. I01).

${ }_{27}$ Nesse sentido, ver orientação de Rothenburg, analisada na subseção 1.2 deste trabalho.

28 "Art. $5^{\circ}$ Todos são iguais perante a lei, sem distinção de Qualeuer natureza, garantindo-se aos brasileiros' e aos estrangeiros residentes no País a inviolabilidade do direito à vida, à líberdade, à igualdade, à segurança $\mathrm{e}$ à propriedade, nos termos seguintes: (...)"

29 Nesse sentido, Aliomar Baleciro define a igualdade como sendo o pilar básico do Estado Democrático de Direito (BALEEIRO, Aliomar. Limitaçöes Constitucionais ao Poder de Tributar. Atualizado por Misabel Abreu Machado Derzi. $7^{\text {a }}$ ed. Rio de laneiro: Forense, [997. p. 525).

30 CANOTILHO, José Joaquim Gomes. Direito Constitucional e Teoria da Constituição. 5 a ed. Coimbra: Livraria Almedina, 2002. p. 348-349.

31 ROCHA, Cármen Lúcia Antuncs. O Princípio Constitucional da lgualdade. Bclo Horizonte: Lê, 1990. p. 70. 
Constituição - Que cuida dos direitos individuais e coletivos - encontra-se em posição de relevo, além de ser o instituto norteador dos direitos reconhecidos e assegurados no dispositivo legal.

A esse respeito, Bastos ${ }^{32}$ elucida Que a função do princípio da igualdade é o de informar e condicionar todo o restante do direito, não assegurando, desse modo, nenhuma situação jurídica específica, mas a má utilização da ordem jurídica.

\subsubsection{Igualdade como Direito Fundamental}

Abordada a posição doutrinária sobre a igualdade como um princípio fundamental e sua evidência no texto constitucional, torna-se interessante, neste momento, discorrer sobre os direitos fundamentais, fá Que o princípio da igualdade está estabelecido no Título ll da Constituição, Que trata dos "Direitos e Garantias Fundamentais", e, em específico, no Capítulo I, que trata dos "Direitos e Deveres Individuais e Coletivos".

Direitos fundamentais, conforme Sarlet ${ }^{33}$, são preceitos jurídicos constitucionais de diversos e importantes conteúdos, relativos às pessoas. Segundo o autor, haja vista o disposto no $\S 2^{\circ} \mathrm{do}$ art. $5^{\circ} \mathrm{da}$ Constituiçãa $0^{34}$, os direitos fundamentais, por possuírem amplo conceito, podem ser encontrados em outras partes do texto constitucional.

Canotitho ${ }^{35}$ ressalta Que a função essencial dos direitos fundamentais é a defesa da pessoa humana e sua dignidade - é a defesa aos direitos dos cidadãos. Para o autor ${ }^{36}$, outra função dos direitos fundamentais é nomeada como a função da não discriminação, Qual seja, assegurar, mediante o princípio da igualdade, Que o Estado trate todos os cidadãos de maneira igual.

32 BASTOS, Ceiso Ribeiro; MARTINS, Ives Gandra. Comentários à Constituigăo do Brasil. $2^{\circ}$ volume. São Paulo: Saraiva, 1989. p. 9, 13.

${ }^{33}$ SARLET, ingo Wolfgang. A Eficácia dos Direitos Fundamentais. $2^{2}$ ed. Porto Alegre: Livraria do Advogado, 2001. p. 77, 82, 91-92.

34 "Art. $5^{\circ}$ Todos são iguais perante a lei, sem distinçăo de qualquer natureza, garantindo-se aos brasileiros e aos estrangetros residentes no País a inviolabilidade do direito à vida, à liberdade, à igualdade, à segurança $\mathrm{e}$ à propriedade, nos termos seguintes: (...) $\S 2^{\circ}$ Os direitos e garantias expressos nesta Constituição não excluem outros decorrentes do regime e dos princípios por ela adotados, ou dos tratados internacionais em Que a República Federativa do Brasil seja parte."

${ }^{35}$ CANOTILHO, josé loaquim Gomes. Direito Constitucional e Teoria da Consitituiçäo. $5^{a}$ ed. Coimbra: Livraria Almedina, 2002. p. 405.

${ }^{36}$ CANOTLLHO, losé loaquim Gomes. Direito Constitucional e Teoria da Constituição. $5^{a}$ ed. Coimbra: Livraria Almedina, 2002. p. 407. 
Adicionalmente, Carrazza ${ }^{37}$ destaca que os direitos fundamentais, além de serem garantias irrenunciáveis e imprescritíveis, são preceitos proibitivos de lesão. Segue o autor frisando Que tais lesões podem vir por meio de leis, atos administrativos ou decisões judiciais e Que, em contrariando tais valores, podem ser anulados com base em sua inconstitucionalidade.

Desta forma, poderia se chegar à conclusão de Que a igualdade é um direito fundamental?

Canotilho $^{38}$ responde tal Questionamento ao afirmar que o princípio da igualdade é um dos princípios que compóem o regime geral dos direitos fundamentais, e Que a igualdade é requisito à regularização das liberdades individuais dos cidadãos sujeitos ao ordenamento jurídico. Fortalece esse posicionamento euando assegura Que o princípio da igualdade não é apenas um princípio de Estado de direito mas também um princípio de Estado social, de justiça social.

A esse respeito, Cármen Rocha ${ }^{39}$ elucida Que a igualdade jurídica encontra-se em posição de direito fundamental individual, social e coletivo, sendo, assim, direito de todos.

Para não restar dúvida, vale referir orientação de Paulo Bonavides ${ }^{40}$, eue alega ser a igualdade o direito garantidor do Estado social, além do direito fundamental de maior importância no direito constitucional.

\subsubsection{Aplicabilidade Imediata}

Concluindo-se sobre a natureza fundamental da igualdade, convém destacar a norma estabelecida no $\S 1^{\circ}$ do artigo $5^{\circ}$ da Constituição $0^{41}$. Haja vista o referido preceito legal salientar a aplicabilidade imediata das normas definidoras dos direitos fundamentais, concluise eue a igualdade jurídica, por ser um direito fundamental, possui aplicabilidade imediata.

Cármen Rocha ${ }^{42}$, nesse sentido, esclarece que o direito à igualdade possui aplicabilidade imediata, e que se encontra materializado também em outras normas que se acoplam ao art. $5^{\circ}$ da Constituição e dão, assim, conteúdo e instrumentalização constitucional necessária a seu aperfeiçoamento.

${ }^{37}$ CARrazZA, Roque Antônio. Curso de Direito Constitucional Tributário. $12^{\text {a }}$ ed. São Pauto: Malheiros Editores, 1999. p. 273.

38 CANOTILHO, losé Joaquim Gomes. Direito Constitucional e Teoria da Constituição. 5a ed. Coimbra: Livraria Almedina, 2002. p. 424.

$3 y$ ROCHA, Cármen Lúcia Antunes. O Princípio Constitucional da lgualdade. Belo Horizonte: Lê, 1990. p. 92.

* BONAVIDES, Paulo. Curso de Direito Consititucional. I la ed. São Paulo: Editores Malheiros, 2001 . p. 341.

4) "Art. $5^{\circ}$ Todos são iguais perante a lei, sem distinção de Qualpuer natureza, garantindo-se aos brasileiros e aos estrangeiros residentes no País a inviolabilidade do direito à vida, à liberdade, à igualdade, à segurança $\mathrm{e}$ à propriedade, nos termos seguintes: (...) § $1^{\circ}$ As normas definidoras dos direitos e garantias fundamentais têm aplicação imediata."

42 ROCHA, Cármen Lúcia Antunes. O Princípio Constitucional da lgualdade. Belo Horizonte: Lê, 1990. p. 71. 
Contudo, Sarlet ${ }^{43}$ expõe Que cabe ao poder público o dever de extrair das normas Que consagram os direitos fundamentais a maior eficácia possível. Além disso, o autor acautela sobre a possibilidade de haver distinções no Que concerne à graduação desta aplicabilidade e eficácia, mesmo entre os direitos fundamentais, sendo Que tal graduação poderá depender da forma de positivação, do objeto e da função Que desempenha cada preceito.

Assim, pode-se dizer que o princípio da igualdade possui importante papel no texto constitucional, não só pelo seu caráter de direito fundamental, como também pelas suas inúmeras funções, dentre elas garantir justiça social, condicionando o poder legislativo aos seus preceitos.

Contudo, mesmo sendo um instituto de destaque consagrado e uma norma possuidora de eficácia plena e aplicabilidade imediata, sua aplicação dependerá de fatores externos à igualdade preceituada - o grau de aplicabilidade do direito à igualdade poderá ser maior ou menor, dependendo do caso ${ }^{44}$.

É valido ainda ressaltar que a igualdade não obteve destaque apenas na Constituição de 1988; ela esteve presente em praticamente todas as Constituições Brasileiras.

Em análise ao artigo $153, \S I^{\circ}$ da Constituição de $1967^{45}$. com redação dada pela Emenda Constitucional $n^{\circ} 01$ de 1969 . Bandeira de Mello ${ }^{46}$ refere Que o princípio da igualdade, além de nivelar os cidadãos, proíbe a edição de lei em desconformidade com a isonomia. $\mathrm{O}$ autor ${ }^{47}$ continua sua análise, consagrando a isonomia como o mais importante princípio garantidor dos direitos individuais.

\subsubsection{Diferenciações e Finalidades}

Voltando-se ao estudo da Constituição de 1988, o texto constitucional especifica em seu art. $5^{\circ}$, caput, Que "todos são iguais perante a lei, sem distinção de QualQuer natureza, garantindo-se aos brasileiros e aos estrangeiros residentes no País a inviolabilidade do direito à vida, à liberdade, à igualdade, à segurança e à propriedade".

${ }^{43}$ SARLET, Ingo Wolfgang. A Eficácia dos Direitos Fundamentais. $2^{a}$ ed. Porto Alegre: Livraria do Advogado, 2001. p. 250-251.

${ }^{4}$ Sobre os requisitos para a aplicação do princípio da igualdade, tal ponto será abordado com mais propriedade na segunda parte deste trabaho.

45 "Art. 153 A Constituição assegura aos brasileiros e aos estrangeiros residentes no Pais a inviolabilidade dos direitos concernentes à vida, à liberdade, à segurança e à propriedade, nos termos seguintes: $\$ 1^{\circ}$ - Todos são iguais perante a lei, sem distinção, de sexo, raça, trabalho, credo teligioso e convicções políticas. O preconceito de raça será punido pela lei."

46 MELLO, Celso Antônio Bandeira de. O Conteúdo /urídico do Princípio da Iguadade. $2^{a}$ ed. Săo Paulo: Revista dos Tribunais, 1984. p. 13.

47 MELLO, Celso Antônio Bandeira de. O Conteúdo /urídico do Princípio da lguadade. $2^{\text {a }}$ ed. São Paulo: Revista dos Tribunais, 1984. p. 58. 
Humberto Ávila ${ }^{48}$ destaca, de maneira peculiar, a fundamental atribuição Que o instituto da igualdade possui no sistema constitucional. Dispóe que a igualdade não se limita apenas como um princípio Que institui um estado igualitário, mas também como uma regra, Que proíbe o tratamento discriminatório, e como um postulado, Que estrutura a aplicação do direito em função de critérios de diferenciação e finalidade.

Já para Alexy ${ }^{49}$, a igualdade é um princípio dirigido ao legislador ${ }^{50}$, mas que não pode ser exigido em todas as propriedades naturais e em todas as situações fáticas, ou seja, não pode haver a exigência de Que todos devam ser tratados exatamente da mesma maneira ou Que todos devam ser iguais em todos os aspectos. Assim, o autor ${ }^{51}$ esclarece que havendo uma razão suficiente para ordenar tratamento desigual, serão admitidas as diferenciações, isto é, o princípio da igualdade exige o tratamento igual para todos, permitindo-se, todavia, tratamento desigual Quando existirem razōes plausíveis para a sua permissão.

A esse respeito, Cármen Rocha ${ }^{52}$ dispõe cue a igualdade constitucional é um modo justo de se viver em sociedade, mas Que a adoção do princípio não significa o término dos critérios diferenciadores das pessoas e situações por elas vividas.

Nesse sentido, pode-se concluir Que o princípio da igualdade não é violado caso os homens não sejam necessariamente iguais no intelecto, na capacidade laboral ou na condição econômica, por exemplo. O Que o princípio realmente expressa é a igualdade perante a lei (igualdade formal) e na lei (igualdade material), chegando-se ao entendimento de que a igualdade deve ser imposta por norma legal voltada à aplicação de tratamento equânime entre as pessoas.

Entretanto, como já visto anteriormente, nem todas as desigualdades são violadoras do princípio da igualdade. Deve-se portanto estabelecer até onde e em Que condições as desigualdades podem ser consideradas legítimas, sem causar injustiça; ${ }^{53}$ em Que circunstância é legítimo discriminar.

48 ÁVILA, Humberto: Teoria dos Princípios: Da definição à aplicação dos princípios jurídicos. $3^{\mathrm{a}}$ ed. São Paulo: Malheiros, 2004. p. $101-102$.

49 ALEXY, Robert. Teoria de Los Derechos Fundamentales. Madrid: Centro de Estudios Constitucionales, 1993. p. 385.

50 Nesse sentido, ver: CANOTLLHO, losé Ioaquim Gomes. Direito Constitucional e Teoria da Constituiçăo. $5^{\mathrm{a}}$ ed. Coimbra: Livraria Almedina, 2002. p. 424; ROCHA. Cármen Lúcia Antunes. OPrincipio Consittucional da Igualdade. Belo Horizonte: Lê, 1990. p. 37.

5 ALEXY, Robert. Teoria de Los Derechos Fundamentales. Madtid: Centro de Estudios Constitucionales, 1993. p. 395-400.

52 ROCHA, Cármen Lúcia Antunes. O Princípio Constifucional da lgualdade. Belo Horizonte: Lê. 1990. p. 45 .

33 Nesse sentido: ROCHA, Cármen Lúcia Antunes, O Principio Constituciona/ da Igualdade. Belo Horizonte: Lê, 1990. p. 34. 
A esse respeito, Bandeira de $\mathrm{Mello}^{54} \mathrm{faz}$ estudo minucioso sobre o reconhecimento das diferenciações e esclarece a necessidade de investigar o critério discriminatório, de verificar se há fundamento lógico para atribuir o específico tratamento jurídico desigual, bem como de analisar se o fundamento lógico está em consonância com os valores prestigiados no sistema normativo constitucional.

Adiciona o autor ${ }^{55}$ Que a discriminação não pode ser gratuita ou fortuita, necessitando de adeQuação entre o tratamento diferençado e a razão para tal diferenciação. Caso isso não ocorra, a distinção estabelecida afronta o princípio da isonomia.

Resumidamente, para o autor ${ }^{56}$, são Quatro os elementos necessários para Que uma diferenciação conviva com a isonomia: a desequiparação deve atingir mais de um indivíduo; as situaçôes ou pessoas desequiparadas devem ser distintas entre si; a existência de correlação entre o fator diferenciador e a distinçâo de regime jurídico em função dele estabelecida pela norma jurídica e; a pertinência da fundamentação em atenção aos interesses constitucionalmente protegidos.

Ainda sobre a existência de tralamentos distintos, Cármen Rocha ${ }^{57}$ esclarece Que a lei não deve abrigar desigualdades sem fundamentação embasada nos critérios de justiça, devendo estar presente, sempre que possivel, o princípio da igualdade, inclusive, se necessário, desigualando alguns aspectos para que o resultado seja o equilíbrio justo e a igualdade material e não meramente formal.

Entretanto, do destaque sobre o necessário equilibrio nos tratamentos a serem concedidos, a autora ${ }^{58}$ chega em um dos porquês da dificuldade de se concretizar e aplicar o princípio constitucional da igualdade - a busca pelo critério justo para a igualação e para a desigualação.

Ao tentar dirimir a dificuldade encontrada, Celso Ribeiro Basto ${ }^{59}$ argumenta que a lei possui sim o papel de distinguir situações, mas o que se deve evidenciar para solucionar o problema da isonomia é a finalidade que a norma legal busca. Ressalta Que o elemento discriminador da norma é uma decorrência do elemento finalidade da norma, năo possuindo o discrímen autonomia para fornecer sozinho o critério de sua validade ou invalidade.

S4 MELLO, Celso Antônio Bandeira de. O Conteúdo /urídico do Princípio da Iguadade. $2^{\text {a }}$ ed. São Pauto: Revista dos Tribunais, 1984. p. 27-28.

5s MELlo, Celso Antônio Bandeira de. O Conteúdo /urídico do Princípio da Iguadade. $2^{\text {a }}$ ed. São Paulo: Revista dos Tribunais, 1984. p. 49.

56 MELLO, Celso Antônio Bandeira de. O Conteúdo furídico do Princípio da lguadade. $2^{\text {a }}$ ed. São Paulo: Revista dos Tribunais, 1984. p. 53-54.

${ }^{57}$ ROCHA, Cármen Lúcia Antunes. O Princípio Constitucional da lgualdade. Belo Horizonte: Lê, 1990. p. 38-39.

${ }^{58}$ Nesse sentido: ROCHA, Cármen Lúcia Antunes. O Princípio Constitucional da lgualdade. Belo Horizonte: Lê, 1990. p. 45.

"BASTOS, Celso Rbeiro; MARTINS, lves Gandra. Comentários à Constituiçăo do Brasil. $2^{\circ}$ volume. Säo Paulo: Saraiva, 1989, p. 9-10. 
Portanto, para Que se saiba Quando o elemento discriminador violou o princípio da isonomia tributária, primeiramente deve-se evidenciar qual finalidade a lei possui.

Tal ressalva Humberto Ávila ${ }^{60}$ também faz, ao analisar Que a concretização do princípio da igualdade depende do critério diferenciador, e que tal diferenciação materializa-se Quando agregada à uma finalidade. Isto é, os contribuintes serão considerados, entre si, iguais ou diferentes de acordo com um mesmo critério diferenciador e de um fim a ser alcançado.

Nesse contexto, Cármen Rocha ${ }^{61}$ afirma Que o critério diferenciador Que não possa ser vinculado ao fim pretendido pela norma jurídica considera-se como inválido, ao passo Que o critério diferenciador de tratamento sócio-econômico, com o fim de garantir a isonomia, somente será aceito Quando, além de válido juridicamente, puder demonstrar a conexão entre a desequiparação normativa e o interesse protegido socialmente.

\section{ISONOMIA COMO UM PRINCÍPIO CONSTITUCIONAL TRIBUTÁRIO}

A estrutura do direito tributário encontra-se na Constituição, ou seja, é no texto constitucional Que estão preceituados os limites ao poder de tributar e onde se estruturam os princípios de natureza tributária, princípios esses Que formam a base de sustentação de todo o sistema tributário ${ }^{62}$. Ocorre Que, conforme visto anteriormente (Quando do estudo dos princípios constitucionais), os princípios dispostos fora do sistema tributário, mas de natureza constitucional, são a base primeira não só do sistema tributário, mas de todo o ordenamento jurídico.

Nessa linha, Carrazza ${ }^{63}$ especifica Que a funcionalidade e a validade dos princípios são colocadas em evidência no direito tributário, já Que eles moldam e interferem nas leis tributárias. Exemplifica o autor ${ }^{64}$, ao referir Que o caput do art. $5^{\circ}$ da Constituição, Que proclama Que todos são iguais perante a lei, interdita a arbitrariedade, inclusive em matéria tributária.

Ademais, Luciano Amaro ${ }^{65}$ afirma Que o princípio da igualdade, pelo fato de ser tanto um princípio constitucional Quanto um axioma basilar do direito tributário, possui abrangência universal.

${ }^{60}$ ÁVILA, Humberto. Teoria dos Princípios: Da definição à aplicação dos princípios jurídicos. $3^{\text {a }}$ ed. São Paulo: Malheiros, 2004. p. 101-102.

6s ROCHA, Cármen Lúcia Antunes. O Principio Constitucional da Igualdade. Belo Horizonte: Lê, 1990. p. 46.

62 Nesse sentido, ver: AMARO, Luciano. Direito Tributário Brasileiro, $2^{\text {a }}$ ed. São Paulo: Saraiva, 1998. p. 158.

63 CARRAZZA, Roque Antônio. Curso de Direito Constitucional Tributário. $12^{\text {z }}$ ed. São Paulo: Malheiros Editores, 1999. p. 37.

ot CARRAZZA, Roque Artônio. Curso de Direito Constitucional Tributário. $12^{\text {a }}$ ed. São Paulo: Malheiros Editores, 1999. p. 300.

65 AMARO, Luciano. Direito Tributário Brasileiro. 2a ed. São Paulo: Saraiva, 1998. p. 203. 
Ocorre Que, mesmo possuindo o art. $5^{\circ}$ da Constituição abrangência universal, o texto constitucional de 1988, em seu art. 150, inciso II, normatizou o principio da igualdade na tributação.

Nesse sentido, José Afonso da Silva ${ }^{66}$ argumenta oue a regra da isonomia estabelecida no caput do art. $5^{\circ}$ da Constituição não foi suficiente para garantir a igualdade perante a tributação. Desta maneira, estabeleceu o contribuinte, no art. I 50, inciso ll, da Constituição, o princípio da isonomia tributária.

\subsection{Vedação à Arbitrariedade}

O artigo [50, inciso II, está disposto no Título VI da Constituição, dedicado à tributação e ao orçamento, e assim preceitua o princípio da isonomia tributária:

Art. 150. Sem prejuízo de outras garantias asseguradas ao contribuinte, é vedado à União, aos Estados, ao Distrito Federal e aos Municípios:

(...)

II - instituir tratamento desigual entre contribuintes Que se encontrem em situação equivalente, proibida Qualquer distinção em razão de ocupação profissional ou função por eles exercida, independentemente da denominação jurídica dos rendimentos, títulos ou direitos:

Tal princípio, conforme referido por Sacha ${ }^{67}$, é um direito individual do contribuinte, de radicação constitucional, onde pessoas em idênticas condições devem ser tributadas igualmente ou devem ser imunes à tributação de modo igual.

Em outra obra sua, o autor ${ }^{68}$ especifica Que o princípio da isonomia tributária trata-se de um princípio constitucional, em matéria tributária, conexo aos direitos fundamentais.

Adicionalmente, Carrazza ${ }^{69}$ especifica Que o princípio em análise visa garantir uma tributação justa, visto Que fora desenvolvido a partir da idéia de justiça. Entretanto, refere Que a garantia de uma tributação justa não significa Que as leis tributárias irão tratar todas as pessoas da mesma maneira, mas Que precisam tratar da mesma maneira as pessoas que se encontrem cm situações idênticas. Ou melhor, Quem está na mesma situação jurídica deve receber o mesmo tratamento tributário.

6 SILVA, losé Afonso da. Curso de Direito Constitucional Positivo. 20a ed. Săo Paulo: Malheiros, 2002. p. 221.

67 COÊLHO, Sacha Calmon Navarro. A Tributação dos Inativos, in Revista Dialética de Direito Tributário, RDDT $n^{\circ} 103$, abril/2004. p. 160.

68 COÊLHO, Sacha Calmon Navarro. Curso de Direlto Tributário Brasileiro. $3^{2}$ ed. Rio de laneiro: Forense, 1999. p. 179-180.

60 CARRAZZA, Roque Antônio. Curso de Direito Constitucional Tributário. $12^{\text {a }}$ ed. São Paulo: Malheiros Editores, 1999. p. 300-301. 
Na visão de Bandeira de $\mathrm{Mello}^{70}$, a igualdade é o princípio que visa propiciar a garantia individual, bem como tolher favoritismos com a proibição de concessão, por lei, de tratamento específico, vantajoso ou desvantajoso, sem fundamentação válida para tal disparidade. Para o autor ${ }^{71}$, o que a ordem jurídica pretende com o princípio da igualdade é garantir a impossibilidade de desequiparações fortuitas ou injustificadas.

Nesse sentido, Canotilho ${ }^{72}$ especifica Que o princípio da igualdade não proíbe a distinção feita por lei, mas o arbítrio, isto é, proíbe as distinções de tratamento sem fundamento suficiente para tanto.

Complementando os entendimentos anteriores, Alexy ${ }^{73}$ afirma Que se há razão suficiente para ordenar um tratamento desigual, então deverá ser ordenado o tratamento desigual. E mais, especifica Que o tratamento não será arbitrário Quando for a melhor ou mais justa solução, bem como Quando existirem razões plausíveis para a sua permissão.

Portanto, conclui-se Que para o tratamento desigual ser legítimo deverá haver uma justificação para tal diferenciaçăo.

Assim, com os argumentos anteriormente analisados, chega-se a um consenso sobre o principal objetivo do princípio da isonomia tributária - a vedação ao tratamento diferenciado em situaçōes idênticas ou ao tratamento idêntico em situações diferenciadas.

\subsection{Requisitos para a aplicação do Princípio da Isonomia Tributária}

Tendo em vista que o princípio da isonomia tributária é uma extensão do direito fundamental à igualdade, cumpre analisar se o princípio possut aplicabilidade limitada, isto é, Quando aplica-se o princípio.

Tal assertiva encontra respaldo em abordagem feita por Baleeiro ${ }^{74}$, Que considera Que a igualdade, entre outros princípios, integra o rol dos direitos e garantias fundamentais do contribuinte. E, como tais, são auto-aplicáveis.

to MELLO, Celso Antônio Bandeira de. O Conteúdo /urídico do Príncípio da lguadade. $2^{\mathrm{a}}$ ed. São Paulo: Revista dos Tribunais, 1984. p. 30, 44-45, 50.

${ }_{71}$ MELlo, Celso Antônio Bandeira de. O Conteúdo /urídico do Princípio da lguadade. $2^{\mathrm{a}}$ ed. Săo Paulo: Revista dos Tribunais, 1984, p. 25.

72 CANOTILHO, losé Joaquim Gomes. Direito Constitucional e Teoria da Constituị̧ăo. $5^{\mathrm{a}}$ ed. Coimbra: Livraria Almedina, 2002. p. 426-427.

73 ALEXY, Robert. Teoria de Los Derechos Fundamentales. Madrid: Centro de Estudios Constitucionales, 1993. p. 395, 397. 400.

74 BALEEIRO, Aliomar. Limitaçöes Constitucionais ao Poder de Tributar. Atualizado por Misabel Abreu Machado Derzi. $7^{\text {a }}$ ed. Rio de Janeiro: Forense, 1997. p. 521. 
É também nesse sentido a manifestação de Sacha ${ }^{75}$, ao entender que os princípios constitucionais tributários traduzem reafirmações e garantias dos direitos fundamentais, sendo, portanto, cláusulas perenes, pétreas, insuprimíveis.

Adicionalmente, Sarlet ${ }^{76}$ também declara Que as normas definidoras dos direitos e garantias fundamentais possuem aplicabilidade imediata.

Que o princípio instituído no art. 150, inciso Il, da Constituição possui aplicação imediata, não resta dúvida. Mas essa aplicação, mesmo sendo imediata, é efetiva? Para garantir sua aplicação não é necessário preencher alguns requisitos?

Baleeiro ${ }^{77}$ esclarece que para a aplicação justa da norma de tratamento igual deve-se seguir alguns requisitos, tais como a imparcialidade, a uniformidade e a regularidade na aplicação. Segue o autor, ao observar que a não aplicação de uma norma válida só pode ser motivada por peculiaridades do caso concreto.

lá para Humberto Ávila ${ }^{78}$, a aplicação da igualdade depende de um critério diferenciador e de uma finalidade a ser alcançada, devendo ser ordenada em virtude de um determinado fim. Complementa o autor, ao especificar que "fins diversos levam à utilização de critérios distintos", ou seja, "fins diversos conduzem a medidas diferentes de controle".

Em outra obra sua, e seguindo o mesmo entendimento, Humberto Ávila ${ }^{79}$ afirma Que a aplicação da igualdade depende dos seguintes elementos: duas ou mais pessoas ou situaçöes, saber Qual medida será empregada na comparação entre as pessoas ou situações e Qual fimm comparativo será utilizado na comparação (finalidade).

Explica-se: a igualdade, no entender do autor, só pode ser definida com vistas a uma finalidade determinada, ao passo que os contribuintes só serão iguais ou diferentes entre si em razão dos critérios a serem utilizados para a comparação.

Ocorre Que destas afirmativas, o autor ${ }^{80}$ conclui pela dificuldade em aplicar ou mesmo em definir o instituto da isonomia, Que possui limitações em si próprio, dependendo sempre de um critério.

${ }^{75}$ COÊltHO, Sacha Calmon Navarro. Curso de Direito Tributário Brasileiro. $6^{\mathrm{a}}$ ed. Rio de laneiro: Forense, 2001. p. 181.

7 SARl. ET, Ingo Wolfgang. A Eficácia dos Direitos Fundamentais. $2^{\text {a }} \mathrm{cd}$. Porto Alegre: Livraria do Advogado, 200I. P. 71.

7 BALEEIRO. Aliomar. Limitaçöes Constitucionais ao Poder de Tributar. Atualizado por Misabel Abreu Machado Derzi. $7^{\text {a }}$ ed. Rio de laneiro: Forense, 1997. p. 533.

*o ÁVILA, Humberto. Teoria dos Princípios: Da definição à aplicação dos principios jurídicos. $3^{\mathrm{a}} \mathrm{ed}$. São Paulo: Malheiros, 2004. p. 102.

* ÁVILA, Humberto. Sistema Constitucional Tributário. São Paulo: Saraiva, 2004. p. 356-358.

80 ÁvILA. Humberto. Sistema Constitucional Tributário. Săo Paulo: Saraiva, 2004. p. 358-359. 
Nessa mesma linha, Luciano Amaro ${ }^{81}$ entende que o princípio da igualdade indica o rumo a ser seguido, mas não permite que se identifịue sua exata dimensão, dificultando, assim, sua aplicação.

Adicionalmente, Misabe ${ }^{82}$, em nota do livro de Aliomar Baleeiro, refere que a dificuldade Quanto à aplicação da igualdade está no critério de comparação e sua valoração: "Qual o critério a ser levado em conta, Que diferenças devem ser desprezadas? Que características são relevantes para agrupar os objetos em consideraçâo?"

Assim, é certo que a aplicação do princípio da isonomia tributária depende de uma série de fatores. Deste modo, na tentativa de entender e de dirimir as dificuldades encontradas para a aplicação do princípio da isonomia tributária, torna-se importante abordar os critérios para as diferenciações de tratamento.

\subsection{Critérios para as Diferenciações}

Em virtude das elucidações feitas na subseção anterior, constatou-se a dificuldade em aplicar e, até mesmo, em definir o princípio da isonomia tributária, haja vista o instituto em estudo depender da análise de uma série de fatores.

Tal dificuldade, para Hugo de Brito Machado ${ }^{83}$, surge da necessidade de avaliar se o legislador pode estabelecer diferenciações e, nesse caso, Quais os critérios que podem ser validamente uttlizados e quais implicam em lesão ao princípio.

Nesse sentido, Celso Bandeira de Mello ${ }^{84}$ salienta a importância de verificar Quais discriminações são juridicamente intoleráveis, ou seja, Qual a espécie de igualdade veda e Que tipo de desigualdade faculta a discriminação de situaçóes e de pessoas, sem Quebra e agressão aos objetivos do princípio da isonomia.

\subsubsection{Capacidade Contributiva}

Como anteriormente analisado, o art. 150, inciso Il, da Constituição especifica Que é vedado instituir tratamento desigual entre contribuintes que se encontrem em situação equivalente.

83 AMARO, Luciano. Direito Tributário Brasileiro. $2^{2}$ ed. Săo Pauto: Saraiva, 1998. p. 108.

82 BALEEIRO, Aliomar. Limitações Constitucionais ao Poder de Tributar. Atualizado por Misabel Abreu Machado Derzi. $7^{a}$ ed. Rio de laneiro: Forense, 1997. p. 526.

${ }^{83}$ MACHADO. Hugo de Brito. Curso de Dircito Tributário. $10^{3}$ ed. São Paulo: Malheiros, 1995. p. 28-29.

${ }^{84}$ MELLO, Celso Antônio Bandeira de. O Conteúdo /urídico do Princípio da lguadade. $2^{\text {a }}$ ed. São Paulo: Revista dos Tribunais, 1984, p. 15-16. 
Nestes termos, Carrazza ${ }^{85}$ argumenta Que, além do princípio isonômico visar a garantia de uma tributação justa, visto Que fora desenvolvido a partir da idéia de justiça, a garantia de uma tributação justa não significa Que as leis tributárias irāo tratar todas as pessoas da mesma maneira, mas Que precisam tratar da mesma maneira as pessoas Que se encontrem em situações idênticas.

Assim, para o direito tributário, torna-se essencial distinguir os contribuintes em funçãoo de suas condições econômicas.

Esta também é a orientação de Sacha ${ }^{86}$, ao estabelecer que o princípio da isonomia tributária impõe ao legislador atenção à capacidade contributiva dos contribuintes, para Que haja a discriminação adequada entre os desiguais e para Que não haja a diferenciação entre os iguais, devendo, sim, receber mesmo tratamento.

A esse respeito, Hugo de Brito Machado ${ }^{87}$ observa Que, para os contribuintes serem igualmente tributados, aquele que tem maior capacidade contributiva deve pagar imposto maior, ou seja, a igualdade consiste na proporcionalidade da incidência à capacidade contributiva.

Desse modo, poderia se dizer que o princípio da isonomia tributária, disposto no inciso Il do art. 150, e o princípio da capacidade contributiva, disposto no $\S 1^{\circ} \mathrm{do}$ art. $145^{88}$. ambos da Constituição, complementam-se?

Para Cármen Rocha ${ }^{89}$, sim. A autora especifica Que os dois princípios em análise são normas de fundamental importância para o sistema constitucional tributário, e Que não podem ser interpretados isoladamente. Segue sua análise, ao afirmar que o art. 150, inciso II, da Constituição, veda a desigualação entre contribuintes que possuam idêntica situação sócio-econômica, impondo respeito à capacidade contributiva do contribuinte.

Nessa mesma linha, Humberto Ávila ${ }^{90}$ esclarece que o princípio da igualdade e o princípio da capacidade contributiva, por possuírem o mesmo conteúdo normativo e o mesmo âmbito de apliçação, estâo intimamente ligados, complementando-se e ajustando-se. Complementando, o autor afirma a capacidade contributiva é o próprio critério geral para a aplicação da igualdade.

${ }^{85}$ CARrazZa, Roque Artônio. Curso de Direito Constitucional Tributário. $12^{2}$ ed. São Paulo: Malheiros Editores, 1999. p. 300-301.

* COÊLHO, Sacha Całmon Navarro. Comentários à Constituíção de 1988: Sistema Tributário. $6^{a}$ ed. Forense: Rio de Janeiro, 1997. p. 328.

87 MACHADO, Hugo de Brito. Curso de Direito Tributário. $10^{\text {a }}$ ed. São Paulo: Málheiros, 1995. p. 28.

38 "Art. 145. A Uniẫo, os Estados, o Distrito Federal e os Municípios poderão instituir os seguintes tributos: (..) $\S 1^{\circ}$ Sempre Que possível, os impostos terão caráter pessoal e serão graduados segundo a capacidade econômica do contribuinte, facultado à administração tributária, especialmente para conferir efetivamente a esses objetivos, identificar, respeitados os direitos individuais e nos termos da iei, o patrimônio, os rendimentos e as ațvidades econômicas do contribuinte."

89 ROCHA, Cármen Lúcia Antunes. O Principio Constitucional da lgualdade. Belo Horizonte: Lê, 1990. p. 93-94.

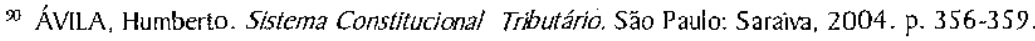


Cumpre ainda salientar que, para Misabel ${ }^{91}$, em nota feita à obra de Aliomar Baleeiro, o princípio da capacidade contributiva, entre outros, é um desdobramento do princípio da igualdade, além de ser um dos critérios de comparação Que inspiram o princípio da igualdade. ${ }^{92}$

Para a autora ${ }^{93}$. o princípio da igualdade, além de ditar o dever do legislador de não discriminar, especifica também o dever de distinguir, para conceder tratamento menos gravoso à̀ueles Que detêm menos capacidade econômica. Isto é, o princípio da igualdade, com o fim de reduzir as grandes disparidades, é invocado para justificar as desigualdades de tratamento.

Assim, não resta dúvida Quanto à ligação Que o princípio da isonomia tríbutária possui com o princípio da capacidade contributiva.

Entretanto, esse não é o único critério a ser analisado para a efetiva aplicação do princípio, podendo haver exceções à proibição de discriminar entre pessoas que demonstram idêntica capacidade contributiva.

\subsubsection{Extrafiscalidade}

Quanto à possibilidade de haver exceções à proibição de discriminar, como anteriormente frisado, tal ponto recebe ênfase no estudo de Sacha ${ }^{94}$. Para o autor, em certas situaçóes o legislador está autorizado a tratar desigualmente os iguais, sem ofensa ao princípio. Tais casos são derivados da extrafiscalidade e do poder de polícia ${ }^{95}$.

A extrafiscalidade, no entendimento de Sacha é a utilização dos tributos para outros fins Que não os da simples arrecadação de meios para o Estado.

2i BALEEIRO, Aliomar. Limitações Constitucionais ao Poder de Tributar. Atualizado por Misabel Abreu Machado Derzi. $7^{\mathrm{a}}$ ed. Rio de laneiro: Forense, 1997. p. 523, 546.

${ }^{92}$ Esse também é o entendimento de Alomar Baleeiro, Que enfatiza ser a capacidade contributiva o princípio fundamental e a fonte principal de critérios discriminatórios (BALEEIRO, Aliomar. Limitaçäes Constitucionais ao Poder de Tributar. Atualizado por Misabel Abreu Machado Derzi. $7^{\text {a }}$ ed. Rio de laneiro: Forense, 1997. p. 520).

93 BALEEIRO, Aliomar. Limitaçöes Constitucionais ao Poder de Tributar. Atualizado por Misabel Abreu Machado Derzi. $7^{2}$ ed. Rio de Janeiro: Forense, 1997, p. 8, 536, 541.

${ }^{4}$ COÊlHO, Sacha Calmon Navarro. Comentálios à Constituição de 1988: Sistema Tributário. $6^{a}$ ed. Forense: Rio de laneiro, 1997. p. 328.

${ }_{95} \mathrm{O}$ autor define o poder de polícia como sendo o poder investido à legisladores e administradores de meios, inclusive fiscais, com a finalidade de limitar direito em beneficio do bem comum, prevalecendo o interesse do todo. 
A esse respeito, Ricardo Lodi Ribeiro ${ }^{96}$ menciona Que o tratamento desigual, preceituado pelo legislador, dado aos contribuintes Que possuem idêntica capacidade contributiva só pode se dar em função da finalidade extrafiscal, também amparada pela Constituição.

Assim, entende-se Que Quando os objetivos são alheios aos meramente arrecadatórios, ou seja, Quando se pretende prestigiar situação social, política e econômica, está se falando em extrafiscalidade.

Com o intuito de corroborar com os argumentos anteriormente expostos, transcrevese trecho de jurisprudência do Supremo Tribunal Federal:

Não há ofensa ao princípio da isonomia tributária se a lei, por motivos extrafiscais, imprime tratamento desigual a microempresas e empresas de peeueno porte de capacidade contributiva distinta, afastando do regime do SIMPLES aQuelas cujos sócios têm condição de disputar o mercado de trabalho sem assistência do Estado.

(BRASIL, Supremo Tribunal Federal, Ação Direta de Inconstitucionalidade 1.643-1. Tribunal Pleno. ReQuerente: Confederação Nacional das Profissões Liberais-CNPL. Reeuerido: Presidente da República. Relator: Ministro Maurício Corrêa. Brasília, 05 de dezembro de 2002. D| 14/03/2003)

Desse modo, em virtude das elucidações expostas neste ponto, torna-se necessário reiterar a importância de analisar a finalidade da norma legal e os critérios que deverão ser levados em conta para a aplicação e para a verificação de violação ao princípio.

Sendo assim, de todo o exposto verifica-se Que inúmeros são os pontos relevantes a serem levados em consideração Quando da análise do princípio da isonomia tributária. Deste modo, os contribuintes devem estar sempre atentos às situações nelas enQuadrados, verificando se estão garantidos pelo princípio da isonomia tributária, ou seja, se o seu direito à igualdade na tributação está sendo respeitado. Contudo, não é dos cidadãos, obviamente, a obrigação de eliminar as desigualdades e equilibrar as condições sócio-econômicas. Tal obrigação deve ser cumprida pelo Estado.

Pertinentemente, Cármen Rocha ${ }^{97}$ menciona Que, além da obrigação Que tem o Estado de não permitir a prevalência de distinções arbitrárias e contrárias à justiça social, há Que revelar a sua obrigação de atuar no sentido de garantir a igualdade. Assim, ao Estado é proibida a criação de discriminações legais, bem como a inércia Quanto a necessária criação de situações de igualação para dirimir desigualdades estabelecidas.

* RIBEIRO, Ricardo Lodi. A Näo-Cumulatividade das Contribuiçōes Incidentes sobre o Faturamento na Constituiç̧ão e nas Leis, in Revista Dialética de Direito Tributário, RDDT no 111 , dezembro/2004, p. 104.

${ }^{97}$ ROCHA, Cármen Lúcia Antunes. O Princípio Constitucional da Igualdade. Belo Horizonte: Lê, 1990. p. $40-42$. 
Portanto, há de prevalecer a igualdade de oportunidades sócio-econômicas e a proibição de favoritismos, de discriminações e de diferenciações entre contribuintes, sem justa fundamentação de sua finalidade. Prevalecendo tais condiçóes, a sociedade terá garantida a efetividade do princípio constitucional da igualdade, tanto na tributação Quanto no ordenamento jurídico como um todo.

\section{CONCLUSÃo}

Em 05 de outubro de 1988 é promulgada a Constituição da República Federativa do Brasil. Constituição essa essencialmente principiológica. Entretanto, mesmo estando garantidos os direitos fundamentais, as desigualdades sociais, juntamente com a arrecadação desmedida de tributos, não param de crescer. A partir dessa perspectiva, este trabalho se propôs a abordar o princípio constitucional da isonomia tributária e a verificação da efetividade de sua aplicação.

Os princípios constitucionais são normas jurídicas de extrema importância no ordenamento jurídico, não só por regulamentarem valores orientadores, mas também por instituírem um comportamento padrão, uma diretriz a ser seguida. São preceitos respaldados em valores fundamentais que têm como função conduzir e orientar outras normas.

Sobre o princípio da igualdade, por ser considerado um dos pilares do Estado Democrático de Direito, possuindo caráter de direito fundamental - de direito garantidor do Estado social - evidencia-se que inúmeras são as suas funções, entre elas, garantir a justiça social e econômica.

Entretanto, mesmo estando o princípio da igualdade disposto no artigo $5^{\circ} \mathrm{da}$ Constituição Federal, tal embasamento legal não foi considerado suficiente pelo constituinte para garantir a igualdade perante a tributação. Assim, o artigo 150, inciso II, da Constituição Federal, estabelece o princípio da isonomia tributária. Visa, o princípio da isonomia tributária, garantir uma tributação justa, devendo a lei ser igual para todos e a todos deve ser aplicada com igualdade.

Todavia, poderá ser permitido tratamento desigual quando houver razão suficiente (justificação) para sua permissão. Uma das razões para a distinção de tratamento é quando os contribuintes encontram-se em condições econômicas diferentes.

Assim, há a necessidade de analisar a condição econômica, ou seja, a capacidade contributiva de cada contribuinte para observar se houve a violação ou não do princípio. $O$ princípio da isonomia tributária impóe ao legislador atenção à capacidade contributiva dos contribuintes, para que haja a discriminação adequada entre os desiguais e para que não haja a diferenciação entre os iguais, devendo, sim, receber mesmo tratamento. 
Nesse sentido, para Que os contribuintes sejam igualmente tributados, deve haver a análise da capacidade contributiva de cada um.

Além disso, é necessário analisar qual o critério diferenciador e qual a finalidade a ser alcançada pela norma jurídica.

Caso a finalidade da norma jurídica supostamente arbitrária seja a extrafiscalidade, está autorizado o tratamento desigual.

Entende-se por extraliscalidade a utilização dos tributos para outros fins eue não os da simples arrecadação de meios para o Estado, ou seja, Quando os obịtivos são alheios aos meramente arrecadatórios.

Sendo assim, importante destacar o papel da capacidade contributiva e da extraliscalidade como critérios de discriminação, critérios esses que auxiliam na verificação do tratamento dado aos contribuintes, ou seja, na verificação se houve violação, ou não, ao princípio da isonomia tributária.

Portanto, conclui-se que o princípio da isonomia tributária, mesmo possuindo papel de destaque no texto constitucional, sua efetiva aplicação depende da análise de uma série de critérios. Assim, evidencia-se a relevância e a complexidade do princípio da isonomia tributária.

\section{REFERÊNCIAS BIBLIOGRÁFICAS}

ALEXY, Robert. Teoria de Los Derechos Fundamentales. Madrid: Centro de Estudios Constitucionales, 1993.

AMARO, Luciano. Direito Tributário Brasileiro. 2a ed. São Paulo: Saraiva, 1998.

ÁVILA, Humberto. Sistema Constitucional Tributário. São Paulo: Saraiva, 2004.

ÁVILA, Humberto. Teoria dos Princípios: Da definição à aplicação dos princípios jurídicos. $3^{\text {a }}$ ed. São Paulo: Malheiros, 2004.

BALEEIRO, Aliomar. Limitaçôes Constitucionais ao Poder de Tributar. Atualizado por Misabel Abreu Machado Derzi. $7^{\text {a }}$ ed. Rio de Janeiro: Forense, 1997.

BASTOS, Celso Ribeiro; MARTINS, Ives Gandra. Comentários à Constituição do Brasil. $1^{\circ}$ volume. São Paulo: Saraiva, 1988.

BONAVIDES, Paulo. Curso de Direito Constitucional 1 l $^{\mathrm{a}}$ ed. São Paulo: Editores Malheiros, 2001 .

CANOTILHO, losé loaquim Gomes. Direito Constitucionale Teoria da Constituição. $5^{\text {a ed. }}$ Coimbra: Livraria Almedina, 2002. 
CARRAZZA, Roque Antônio. Curso de Direito Constitucional Tributário. $12^{\mathrm{a}}$ ed. São Paulo: Malheiros Editores, 1999.

COÊLHO, Sacha Calmon Navarro. A Tributação dos Inativos, in Revista Dialética de Direito Tributário, RDDT n ${ }^{\circ} 103$, abril/2004.

COÊLHO, Sacha Calmon Navarro. Comentários à Constituição de 1988. Sistema Tributário. $6^{a}$ ed. Forense: Rjo de Janeiro, 1997.

COÊLLHO, Sacha Calmon Navarro. Curso de Direito Tributário Brasileiro. $3^{a}$ ed. Rio de Janeiro: Forense, 1999.

GRAU, Eros Roberto. Ensaio e Discurso sobre a Interpretação/Aplicação do Direito. $3^{\text {a }}$ ed. São Paulo: Malheiros Editores, 2005. p. 153, 183.

KELSEN, Hans. Teoria Pura do Direito. Tradução de loão Baptista Machado. $6^{a}$ ed. São Paulo: Martins Fontes, 1998.

MACHADO, Hugo de Brito. Curso de Direito Tributário. $10^{a}$ ed. São Paulo: Malheiros, 1995.

MELlo, Celso Antônio Bandeira de. Elementos de Direito Administrativo. $1^{\text {a }}$ ed. São Paulo: Revista dos Tribunais, 1987.

MELLO. Celso Antônio Bandeira de. O Conteúdo /urídico do Princípio da lguadade. $2^{\mathrm{a}} \mathrm{ed}$. São Paulo: Revista dos Tribunais, 1984.

RIBEIRO, Ricardo Lodi. A Näo-cumulatividade das Contribulfôes Incidentes sobre o Faturamento na Constituição e nas Leis, in Revista Dialética de Direito Tributário, RDDT no $1 / 1$, dezembro/2004. Lê, 1990 .

ROCHA, Cármen Lúcia Antunes. O Principio Consitucional da Igualdade. Belo Horizonte:

ROTHENBURG, Walter Claudius. Princípios Constitucionais. Porto Alegre: Sergio Antonio Fabris Editor, 1999.

SARLET, Ingo Wolfgang. A Eficácia dos Direitos Fundamentais. $2^{\mathrm{a}}$ ed. Porto Alegre: Livraria do Advogado, 2001 .

SILVA, José Afonso da. Curso de Direito Constitucional Positivo, 20a ed. São Paulo: Malheiros, 2002. 